\title{
An approach to the implementation of neuromarketing techniques by European private TV broadcasters
}

\author{
Verónica Crespo-Pereira; Pilar García-Soidán; Valentín-Alejandro Martínez- \\ Fernández
}

How to cite this article:

Crespo-Pereira, Verónica; García-Soidán, Pilar; Martínez-Fernández, Valentín-Alejandro (2019). “An approach to the implementation of neuromarketing techniques by European private TV broadcasters". El profesional de la información, v. 28, n. 5, e280504.

https://doi.org/10.3145/epi.2019.sep.04

Manuscript received on $8^{\text {th }}$ Mar 2019 Accepted on $20^{\text {th }}$ May 2019

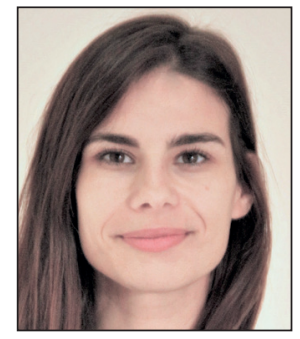

Verónica Crespo-Pereira $\square$ http://orcid.org/0000-0001-7373-7204

Pontificia Universidad Católica del Ecuador. Sede Ibarra

Escuela de Comunicación Social

Av. Jorge Guzmán Rueda y Av. Aurelio

Espinosa Pólit, Ciudadela La Victoria

Ibarra, Ecuador

veronicacrespopereira@gmail.com

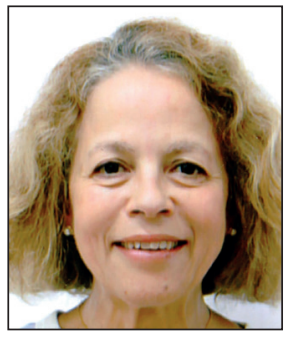

Pilar García-Soidán

https://orcid.org/0000-0003-4542-6630

Universidad de Vigo

Facultad de Ciencias Sociales y de la

Comunicación

Campus A Xunqueira, s/n.

36005 Pontevedra, Spain

pgarcia@uvigo.es

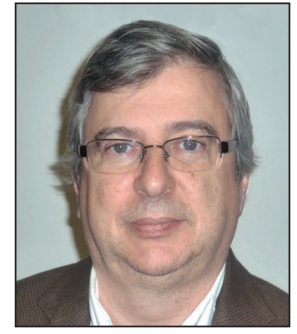

\section{Valentín-Alejandro Martínez- \\ Fernández \\ http://orcid.org/0000-0003-0069-675X}

Universidad de A Coruña

Facultad de Ciencias de la Comunicación

Campus Elviña, s/n. 15071, A Coruña, Spain

valejand@udc.es

\begin{abstract}
Changes on media context urge companies to adopt alternative and innovative strategies for decision-making regarding audience's habits and preferences. In this respect, the neuroscience methodology provides an appealing option to analyze consumers' viewing experience. This paper aims to determine the impact of neuromarketing on TV channels for the latter purpose, through an in-depth review and a survey addressed to analyze the use of this methodology by European private broadcasters. The results achieved point to the potential of neuromarketing to improve efficacy of linear and non-linear TV commercial spaces, as well as to design television contents and to optimize the impact of social TV and multiscreen viewing.
\end{abstract}

\section{Keywords}

Neuromarketing; Private broadcasters; Television; Entertainment industry; Neuroscience; Europe; Media; Audience; Habits; Consumers; Strategies; Decision making; Impact; Optimization.

\section{Introduction}

Audience data has always been the core of broadcaster business. Traditionally, TV channels have made decisions based on demographic, geographical and time-based information. This has been until now, but cognitive neuroscience has changed media research perspectives. Neuroscientific studies have demonstrated the predominance of emotion in decision-making by revealing unconscious emotional processes in the lead of our choices (Bechara; Damasio, 2004). This discovery has driven new paradigms to approach social sciences and media research (Bagozzi; Gopinath; Nyer, 1999) and provoked the emergence of interdisciplinary fields such as neuromarketing. 
Neuromarketing is the application of neuroscientific methodologies to study humans in relation to market stimuli (Fugate, 2007). It emerges from the combination of neuroscience, cognitive psychology and marketing, and aims at identifying the correlation between Central (Fugate, 2008) and Peripheral Nervous System activation to commercial inputs (Santos et al., 2015). Its methods help to refine individuals' behavior since they identify introspective cognitive and emotional processing implicated in preferences (Bechara; Damasio, 2004; Vecchiato et al., 2011) and eliminate the recall bias observed in traditional research (Falk et al., 2010).

Entertainment industry is highly aware of the role of emotion in content designing and its ability to attract attention, entertain, persuade and be remembered (Bolls; Lang; Potter, 2001). Neuromarketing considers the neurophysiologic reactions to design and predict responses to communication stimuli (Bell et al., 2018; Harris; Ciorciari; Gountas, 2018; Hakim; Levy, 2019) that could lead to greater effectiveness on companies' managerial actions. Previous research analyzed the adoption of neuromarketing methodologies by the Spanish broadcasters and by the European public media (Crespo-Pereira; Martínez-Fernández; García-Soidán, 2016; Crespo-Pereira; Martínez-Fernández; Campos-Freire, 2017). Then, the current study offers an exploratory study in the lacking private European sector.

\section{Methodology}

This paper provides a preliminary analysis on a trendy phenomenon observed among worldwide private broadcasters, namely, the implementation of consumer neuroscience methods to study audiences. This research is composed of two parts. In the first one, an in-depth review about the scope of neuromarketing on broadcasters is provided from peer-reviewed articles indexed in the academic data bases: Scopus and Web of Science, and the publisher Emerald. Articles were selected by using the keywords 'Neuroscience' AND 'Television'; 'Neuromarketing' AND 'Television'. Given that broadcasters' commissioned studies are unusual in academic journals (Fischer; Chin; Klitzman, 2010), a complementary search was carried out in the data base Warc and in neuromarketing consultancies' websites. A total of 59 articles and documents were selected, encoded and classified.

The second part of the study analyzes, through an empirical research, the implementation of neuroscientific techniques by European broadcasters. Neuromarketing experts from European countries report about the impact of this innovative methodology in the entertainment industry. With this aim, a personal survey was addressed to specialists selected from the International Neuromarketing Science \& Business Association (Nmsba), as this procedure was validated (Pop; Dabija; lorga, 2014). Given the existence of the previous research (Crespo-Pereira; Martínez-Fernández; García-Soidán, 2016; Crespo-Pereira; Martínez-Fernández; Campos-Freire, 2017), the Spanish consultancies and the European public broadcasters were excluded from this study. Then, from the remaining 33 consultancies, a panel of 14 experts agreed to collaborate in this research, distributed by country as follows: Germany (4), United Kingdom (2), Italy (2), Finland (1), Belgium (1), Denmark (1), France (1), Romania (1) and Netherlands (1) (Table 1).

The data were collected through online self-report questionnaires, designed from the basis of the above mentioned previous similar studies in the Spanish and European setting. A Likert scale, ranging from 1 to 10 (1=completely disagree, $10=$ completely agree), was selected for the responses to more than 30 questions for assessment on various issues. Additional open questions were included, to allow the experts to clarify their responses. The Excel program provided analytical and

Table 1. Panel of neuromarketing experts

\begin{tabular}{|l|l|}
\hline \multicolumn{1}{|c|}{ Expert } & \multicolumn{1}{c|}{ Company } \\
\hline Mév Bertrand & Neuro-Insight (United Kingdom) \\
\hline Duncan Smith & MindLab (United Kingdom) \\
\hline Arnaud Petre & Brain Impact (Belgium) \\
\hline Dr. Thomas Zoëga Ramsøy & Neurons Inc. (Denmark) \\
\hline Philipp Reiter & Eye Square FmbH (Germany) \\
\hline Jarkki Kotola & Exakti Intelligence Oy (Finland) \\
\hline Dr. Simone Benedetto & TSW (Italy) \\
\hline Ana lorga & Buyer Brain (Romania) \\
\hline Dr. Roeland Dietvorst & Alpha.One (The Netherlands) \\
\hline \multirow{5}{*}{ Non identified experts } & Incore GmbH (Germany) \\
\cline { 2 - 3 } & Ottosunove (Italy) \\
\cline { 2 - 3 } & Non identified consultancy (Germany) \\
\cline { 2 - 3 } & Non identified consultancy (Germany) \\
\cline { 2 - 3 } & Non identified consultancy (France) \\
\hline
\end{tabular}
graphical results.

\section{Results}

\subsection{Neuromarketing studies driven by international private broadcasters}

Neuroscience techniques point to an intimate relationship between the presentation of audiovisual stimuli and neurobiological content processing in real time that would result in better knowledge of audience's preferences (Fugate, 2007; Treutler; Levine; Marci, 2010). It helps to provide basic rules to elicit high levels of emotion, attention, memory, affections and understanding (Lang et al., 2000; Lang; Potter; Grabe, 2003) that leads into creative decisions based on neurophysiologic responses to reduce failure (Table 2).

Consumer neuroscience is encouraging entertainment industry to create their own labs to explore cutting-edge equipment in the study of consumer behavior. Nielsen has acquired Neurofocus (2011) and Innerscope (2015) to create Niel- 
sen Consumer Neuroscience and become the largest neuromarketing solution organization (Nielsen, 2011; 2015). Time Warner partnered with Innerscope (Innerscope Research, 2014) to set up Time Warner Medialab which aims at testing consumer engagement across several technology and distribution platforms. Many international media groups, such as Time Warner, CBS, A \& E, Cartoon Network, ESPN (Babu; Vidyagasar, 2012; Innerscope Research, 2014; Singer, 2010), Channel 7, Channel 9, Channel 10, Vevo, Fox Entertainment Group and Turner Broadcasting have invested on neuromarketing research.

Literature review reveals three types of products tested with neuromarketing methodology:

a) TV shows and their promotional campaigns (Table 2),

b) advertising spaces (Table 3),

c) social TV and multi-screening viewing experience (Table 4).

Neuromarketing methods are highly interesting for broadcasters due to their capability to provide creativity insights at early stages of concept development and to determine which aspects elicit audience's best unconscious emotional engagement and attention (Table 2). Entertainment events and pilots are the main TV contents tested with neuromarketing methods, however, the test of TV-show promotional campaigns seems to have a greater presence (Table 2).

Table 2. TV content studies driven by private broadcasters

\begin{tabular}{|c|c|c|c|c|}
\hline $\begin{array}{l}\text { Broadcaster / } \\
\text { practitioner }\end{array}$ & Research & Main results & Techniques & Source \\
\hline $\begin{array}{l}\text { Spike TV / } \\
\text { Not specified }\end{array}$ & $\begin{array}{l}\text { Viewing preferences } \\
\text { of multicultural } \\
\text { audience demo- } \\
\text { graphics over TV } \\
\text { content }\end{array}$ & $\begin{array}{l}\text { Humor, suspense, action, relatable situations and } \\
\text { displays of skill are engagement factors to all kind } \\
\text { of cultures. Differences over audience segments are } \\
\text { shown. }\end{array}$ & Not specified & Warc, 2017 \\
\hline $\begin{array}{l}\text { Spike TV / } \\
\text { Neuro-Insight }\end{array}$ & $\begin{array}{l}\text { TV-show campaign } \\
\text { efficacy }\end{array}$ & $\begin{array}{l}\text { Neuroscience structured TV-show } \\
\text { promotional content achieving an optimal emo- } \\
\text { tional engagement and long term memory on the } \\
\text { scheduling information. }\end{array}$ & $\begin{array}{l}\text { Brain activity } \\
\text { (not specified) }\end{array}$ & $A R F, 2016$ \\
\hline $\begin{array}{l}\text { Spike TV / } \\
\text { Neuro-Insight }\end{array}$ & $\begin{array}{l}\text { Emotional experien- } \\
\text { ce during TV show } \\
\text { viewing. }\end{array}$ & $\begin{array}{l}\text { It determined the most engaged } \\
\text { moments of the show and revealed key aspects to } \\
\text { attract audience. }\end{array}$ & $\begin{array}{l}\text { Biometrics } \\
\text { (heart rate, respira- } \\
\text { tion, motion, skin } \\
\text { sweat) }\end{array}$ & Cablefax Staff, 2011 \\
\hline CBS / Neurofocus & $\begin{array}{l}\text { TV show campaign } \\
\text { and pilots and new } \\
\text { shows efficacy }\end{array}$ & Not specified & Not specified & $\begin{array}{l}\text { Penenberg, 2011; } \\
\text { Consumer 360, } 2012\end{array}$ \\
\hline $\begin{array}{l}\text { The Weather Chan- } \\
\text { nel / Not specified }\end{array}$ & $\begin{array}{l}\text { TV promotional } \\
\text { pitches for a series }\end{array}$ & Not specified & Not specified & $\begin{array}{l}\text { Babu; Vidyagasar, } \\
2012\end{array}$ \\
\hline $\begin{array}{l}\text { Viacom Media } \\
\text { Networks / Not } \\
\text { specified }\end{array}$ & $\begin{array}{l}\text { Programming and } \\
\text { marketing content }\end{array}$ & Not specified & Not specified & $\begin{array}{l}\text { Innerscope Research, } \\
2014\end{array}$ \\
\hline
\end{tabular}

Most advertising models rely on exposition and attention as the previous step to influence emotional and cognitive responses and, therefore, memory and purchase behavior (Woltman-Elpers, 2003). An optimal visibility and impact of marketing stimuli on audience is considered critical for broadcasters' revenues. Many of the research elicited by private broadcasters is focused on this matter. Literature review indicates research is mainly centered on developing efficient strategies for linear and convergent commercial spaces to achieve a better return on investment for advertisers (Table 3).

The measure of audience's involvement with commercial messages might become an indicator of advertising rates (Zurawicki, 2010). Private media companies have approached neuromarketing methods to demonstrate the advantages of advertising on television in collaboration to other media (Fugate, 2007). Their methods enable channels to dig into the benefits of contextual advertising (Zurawicki, 2010). Contextualized and integrated ads on TV shows are proved to get high levels of engagement and recall in audience (Treutler; Levine, 2010). In this respect, ad formats testing and their impact on viewers are usual issues addressed by sport channels (Table 3).

New TV viewing experiences, encouraged by modern technologies (DVR, 4K and Virtual Reality), have promoted studies around their impact in advertising spaces. Neuromarketing helps to structure efficient storytelling in Virtual Reality scenarios for commercial purposes and to determine the impact of $4 \mathrm{~K}$ television in terms of arousal, attention and engagement. DVR (designed to skip ads) is in the spotlight of commercial and academic research to provide implementable tips into commercial content design. Recent
The measure of audience's involvement with commercial messages might become an indicator of advertising rates 
studies conclude that ad stimuli are processed unconsciously during flash-forward (Bartelme, 2012; Siefert et al., 2008) and low emotional spots are $25 \%$ more likely to be flash-forwarded (Zurawicki, 2010).

Table 3. Neuromarketing studies: television as a commercial space

\begin{tabular}{|c|c|c|c|c|}
\hline Broadcaster & Research & Main results & Techniques & Source \\
\hline $\begin{array}{l}\text { Warner Bros / } \\
\text { Innerscope Research }\end{array}$ & $\begin{array}{l}\text { Integrated advertising } \\
\text { on TV shows }\end{array}$ & $\begin{array}{l}\text { TV content can stimulate ads engagement. Engage- } \\
\text { ment is higher when rousing curiosity, consumer be- } \\
\text { nefit data is provided, and the message is integrated } \\
\text { in the jokes and stories on the show. }\end{array}$ & Not specified & $\begin{array}{l}\text { Treutler; Levine; } \\
\text { Marci, } 2010\end{array}$ \\
\hline $\begin{array}{l}\text { Turner Broadcasting / } \\
\text { Innerscope Research }\end{array}$ & $\begin{array}{l}\text { Contextualized adver- } \\
\text { tising }\end{array}$ & $\begin{array}{l}\text { Ad engagement is higher when contextualized } \\
\text { shows. }\end{array}$ & Not specified & $\begin{array}{l}\text { Treutler; Levine; } \\
\text { Marci, } 2010\end{array}$ \\
\hline CBS / Not specified & $\begin{array}{l}\text { Media planning and } \\
\text { efficacy }\end{array}$ & Not specified & Not specified & $\begin{array}{l}\text { Consumer 360, } \\
2012\end{array}$ \\
\hline $\begin{array}{l}\text { A\&E / } \\
\text { TelevisionNeuroFocus }\end{array}$ & $\begin{array}{l}\text { Contextualized adverti- } \\
\text { sing on TV content }\end{array}$ & Not specified & $\begin{array}{l}\text { Neurological } \\
\text { reactions }\end{array}$ & Penenberg, 2011 \\
\hline Turner Broadcasting & $\begin{array}{l}\text { Ads design efficacy } \\
\text { while sport competition } \\
\text { broadcasting }\end{array}$ & $\begin{array}{l}\text { Customized and same creative designs ads are more } \\
\text { engaging than non-customized and different design } \\
\text { ads. }\end{array}$ & & Warc, 2016 \\
\hline $\begin{array}{l}\text { Fox Sports / } \\
\text { Innerscope Research }\end{array}$ & $\begin{array}{l}\text { Double box ad format } \\
\text { efficacy during sport } \\
\text { competition broadcas- } \\
\text { ting }\end{array}$ & $\begin{array}{l}\text { Engagement enhances the interaction between the } \\
\text { viewers and the ad. Double box format is processed } \\
\text { below conscious awareness. }\end{array}$ & $\begin{array}{l}\text { Biometric and } \\
\text { eye-tracking }\end{array}$ & $\begin{array}{l}\text { Innerscope Re- } \\
\text { search, } 2014\end{array}$ \\
\hline ESPN / NeuroFocus & $\begin{array}{l}\text { Graphic design efficacy } \\
\text { on ads and sponsors }\end{array}$ & Not specified & Not specified & Penenberg, 2011 \\
\hline $\begin{array}{l}\text { Television Bureau of } \\
\text { Canada / Innerscope }\end{array}$ & $\begin{array}{l}\text { Emotional response to } \\
\text { advertising on different } \\
\text { media (TV, online, radio, } \\
\text { press) }\end{array}$ & $\begin{array}{l}\text { Ads take advantage of immersive and emotional TV } \\
\text { content. }\end{array}$ & $\begin{array}{l}\text { Biometric and } \\
\text { eye-tracking }\end{array}$ & $\begin{array}{l}\text { Treutler; Levine; } \\
\text { Marci, } 2010\end{array}$ \\
\hline $\begin{array}{l}\text { Time Warner / } \\
\text { Nielsen }\end{array}$ & $\begin{array}{l}\text { Impact of advertising } \\
\text { and TV shows on a vir- } \\
\text { tual reality context. }\end{array}$ & $\begin{array}{l}\text { This study revealed key aspects to virtual reality } \\
\text { efficient storytelling. }\end{array}$ & $\begin{array}{l}\text { Eye-tracking, } \\
\text { EEG and bio- } \\
\text { metrics }\end{array}$ & Swant, 2016 \\
\hline MTV/ Neurosense & $\begin{array}{l}\text { Viewers' engagement } \\
\text { with MTV }\end{array}$ & $\begin{array}{l}\text { MTV is more engaging than other media brands. } \\
\text { Multi-platform has high impact on positivity and } \\
\text { emotional engagement that benefit brands. Respon- } \\
\text { ses came from } 10 \text { countries. }\end{array}$ & $\begin{array}{l}\text { Online implicit } \\
\text { association test } \\
\text { and face trace } \\
\text { analysis }\end{array}$ & Warc, 2015 \\
\hline $\begin{array}{l}\text { Currys, PC World, BT } \\
\text { Sport, M\&C Saatchi / } \\
\text { Sensum }\end{array}$ & $\begin{array}{l}\text { Impact of } 4 \mathrm{~K} \text { in sport } \\
\text { viewing experience }\end{array}$ & $\begin{array}{l}\text { 4K produces higher arousal than HD. Replay on } 4 \mathrm{~K} \\
\text { registers more attention levels than on HD. Engage- } \\
\text { ment in HD strongly depends on the team perfor- } \\
\text { mance whereas } 4 \mathrm{~K} \text { is less dependent on this element. } \\
\text { Replays hold more audience attention in } 4 \mathrm{~K} \text {. }\end{array}$ & GSR & Sensum, 2016 \\
\hline $\begin{array}{l}\text { NCB Universal / } \\
\text { Innerscope Research }\end{array}$ & $\begin{array}{l}\text { Advertising processing } \\
\text { during fast-forwarded } \\
\text { viewing }\end{array}$ & $\begin{array}{l}\text { Audience processes images on a non-conscious level } \\
\text { from flash-forwarding. Viewers are on alert and focus } \\
\text { in the center of the screen when flash-forwarding } \\
\text { and ad recall is significantly high. }\end{array}$ & $\begin{array}{l}\text { Biometric and } \\
\text { eye-tracking }\end{array}$ & $\begin{array}{l}\text { Siefert et al., } \\
2008\end{array}$ \\
\hline
\end{tabular}

Social TV and second screens are called to define new broadcaster business models (Treleaven-Hassard et al., 2010). Private channels have promoted neuroscience-based-research to analyze social TV and multi-screening devices under two main goals, optimizing viewing experience and determining the benefits of cross-platforms synergies in advertising (Table 4). 
Table 4. Social TV and multi-platform studies driven by private broadcasters

\begin{tabular}{|c|c|c|c|c|}
\hline $\begin{array}{c}\text { Broadcaster and } \\
\text { practitioner }\end{array}$ & Research & Main results & Techniques & Source \\
\hline $\begin{array}{l}\text { Fox Broadcasting Company / } \\
\text { Innerscope Research }\end{array}$ & $\begin{array}{l}\text { Immersive platforms } \\
\text { affect engagement with } \\
\text { novel and familiar brand } \\
\text { and synergy between } \\
\text { cross-platforms and brand } \\
\text { associations. }\end{array}$ & $\begin{array}{l}\text { Immersive TV context produces lasting } \\
\text { emotional connections that benefits } \\
\text { brands. Incorporating elements of the TV } \\
\text { content in the online context can increase } \\
\text { the level of engagement in online ads. }\end{array}$ & $\begin{array}{l}\text { Biometrics, } \\
\text { eye-tracking }\end{array}$ & Steele et al., 2013 \\
\hline $\begin{array}{l}\text { Turner Broadcasting / } \\
\text { Innerscope Research }\end{array}$ & $\begin{array}{l}\text { Influence of social TV on } \\
\text { millennials }\end{array}$ & $\begin{array}{l}\text { Social TV drives more emotional engage- } \\
\text { ment on linear TV than solo TV viewing. TV } \\
\text { engagement increases by complementing } \\
\text { TV content with social media and apps. }\end{array}$ & $\begin{array}{l}\text { Biometrics, mo- } \\
\text { bile eye-trac- } \\
\text { king }\end{array}$ & $\begin{array}{l}\text { Innerscope Re- } \\
\text { search, } 2014\end{array}$ \\
\hline $\begin{array}{l}\text { Seven Network / } \\
\text { Neuro-Insight }\end{array}$ & $\begin{array}{l}\text { Social media impact on TV } \\
\text { viewing }\end{array}$ & $\begin{array}{l}\text { Multiscreen encourages high levels of } \\
\text { engagement and long-term memory that } \\
\text { ads would benefit. }\end{array}$ & $\begin{array}{l}\text { Steady state } \\
\text { topography }\end{array}$ & $\begin{array}{l}\text { Pynta et al., 2014; } \\
\text { Seixas et al., } 2015\end{array}$ \\
\hline $\begin{array}{l}\text { CNN/ } \\
\text { Innerscope Research }\end{array}$ & $\begin{array}{l}\text { Advertising impact of } \\
\text { recommended news in } \\
\text { online context }\end{array}$ & $\begin{array}{l}\text { Friend recommended stories on social } \\
\text { media are five times more engaging than } \\
\text { non-recommended ones. Recommen- } \\
\text { ded stories engage more positively to } \\
\text { the message and to associated ads than } \\
\text { non-recommended ones. }\end{array}$ & Biometrics & $\begin{array}{l}\text { Bartelme, 2012; } \\
\text { Nielsen, } 2016 .\end{array}$ \\
\hline $\begin{array}{l}\text { Turner Broadcasting / } \\
\text { Innerscope Research }\end{array}$ & $\begin{array}{l}\text { Second screen sync apps' } \\
\text { attention and emotional } \\
\text { engagement to program- } \\
\text { ming and advertising }\end{array}$ & $\begin{array}{l}\text { Attention drops during commercials. The } \\
\text { optimization of the two-screen expe- } \\
\text { rience depends on integrating ads in the } \\
\text { program content. }\end{array}$ & $\begin{array}{l}\text { Biometrics and } \\
\text { eye-tracking }\end{array}$ & $\begin{array}{l}\text { Aversano; Marsh; } \\
\text { Shalhoub, } 2014\end{array}$ \\
\hline $\begin{array}{l}\text { Innerscope Research } \\
\text { commissioned study by an } \\
\text { anonymous client }\end{array}$ & $\begin{array}{l}\text { Ad efficiency in different } \\
\text { devices and social media }\end{array}$ & $\begin{array}{l}\text { There is a positive synergy between linear } \\
\text { TV and social TV for advertisers. TV ads } \\
\text { impact better than solo social media. } \\
\text { Facebook ads engage four times less than } \\
\text { on TV, therefore, the recall is lower. } \\
\text { The size of the screen is related to adverti- } \\
\text { sing efficacy. } \\
\text { Ads must be designed specifically to } \\
\text { different devices. } \\
\text { Visual attention is related to screen size } \\
\text { and is more difficult to achieve in smaller } \\
\text { screens. Emotional peak should be in the } \\
\text { first few seconds in small screens. }\end{array}$ & $\begin{array}{l}\text { Biometrics, } \\
\text { eye-tracking } \\
\text { and traditional } \\
\text { surveys }\end{array}$ & $\begin{array}{l}\text { Innerscope Re- } \\
\text { search, } 2015\end{array}$ \\
\hline
\end{tabular}

\subsection{Presence of neuromarketing research by European private broadcasters}

Advertising efficacy is critical for broadcasters (TF1 Publicité, 2015), especially in Europe, where neuroscience methods and teams have been incorporated to impulse content and advertising efficiency. TF1 Publicité, the commercial division of the French TF1, has incorporated cognitive science to study memory in the advertising scenario (Bénilde, 2016) and counts with specialized neuropsychology consultants (Cohen, 2005). Also, TF1 Publicité and Canal+ benefit from TV ad efficacy neuroscience studies encouraged by the French Syndicat National de la Publicité Télévisée (Snptv, 2003; 2005).

In Italy, Mediaset's RTI Interactive Media Department is composed of psychologists to offer an innovative connection with audience and social media (Pratesi; Mattiacci, 2015). This department has financed studies with the consultancy Brain2Market to measure the level of attention, emotion and usability on interactive screens (Brain2Market, 2016). Mediaset Spain has studied the emotions triggered by prime time TV series pilots in order to optimize their products and Atresmedia to gain advertising effectiveness (Crespo-Pereira; Martínez-Fernández; García-Soidán, 2016). The German ProSiebenSat.1 Mediagroup uses consumer neuroscience to design TV contents to reduce economical risks (Marktforshung, no date). RTL Klub (Synetiq, n.d.) and RTL Nederland (Crunchbase, n.d.) have also made use of these techniques.

ITV has applied neuroscience to demonstrate the benefits of maintaining a regular brand presence on programs (Neurosense, n.d.). Channel 4 is financing academic research to gain viewer insights in the advertising context and product placement (Thinkbox, 2015; Oakes, 2016), whereas GMTV to compare viewers' advertising receptiveness in the morning versus prime time hours to find persuasive arguments to sell commercial spaces (Haq, 2007). New TV platforms have arisen a discussion of how neuroscience might help to managerial actions. Given the lack of studies around video on demand (VOD) platforms, Channel 4 has pioneered investigations about key aspects for advertising industry such as memory (Ellis; Greenbank, 2015).

Primary research is described next. According to the consultants' opinion, neuromarketing research is believed to have less implementation in their own countries (mean-3,7 and standard average-2,1), than across Europe (mean-4,6 and standard average-2,1). The data from the latter variable, disaggregated by country, are plotted in Figure 1. Denmark and United 
Kingdom achieve the highest rates, whereas a low implementation is observed in Italy and Romania. Northern broadcasters tend to be more receptive to neuromarketing research than the remaining European countries.

Few neuromarketing consultancies have TV networks as clients, $57,1 \%$ of them do not provide services to broadcasters and those offering them are mainly focused on national private $(42,9 \%)$ and public broadcasters $(35,7 \%)$ (Figure 2). Services to private broadcasters represent the 9,3\% of their total volume of work, although some dispersion is observed among the participants (standard deviation of $11 \%$ ).

TV2 Norway, TV2 Denmark, Pro7Sat1 or ITV are among the European private companies that have incorporated neuroscience techniques. The consultancies contacted confirmed that they also provide public corporations with their services, where they observe a similar pattern by country. Public organizations using this methodology include the following ones: Danish Radio, Norwegian Broadcast Company, ARD, ZDF, $B B C$ and Channel 4.

The lack of awareness of neuromarketing and its benefits $(6,9)$ and the fear to try

$(6,6)$ configure the main barriers to implement this methodology by European broadcasters (Figure 3). Neuromarketing is mainly used to improve commercial spaces efficacy $(5,9)$, although its capability to create better entertainment content is also valued $(5,1)$. The current employment of neuromarketing relies on the innovative nature of some private broadcasters $(5,4)$, which can encourage other media companies to integrate these methods in a near future $(5,3)$. Consumer neuroscience still needs to develop and consolidate its know-how in the entertainment industry field. Experts point out some limitations as the lack of knowledge on their performance or the interpretation of the resulting data $(4,9)$. The opaque nature of commercial studies makes it difficult to share a feedback that would enrich research. There is a full agreement that ethics and the existing number of neuromarketing consultancies do not prevent broadcasters from using these methods.

Big data provide channels with significant demographic, geographic and psychographics audience's insights. However, its appearance should not affect neuro-based-research since alternative methods will not necessarily give a better value for money than neuromarketing. Indeed, this research can reveal hidden information from consumers, generalizable to a larger population.
Experts point out some limitations as the lack of knowledge on their performance or the interpretation of the resulting data 
European private broadcasters finance most studies to increase the efficiency of advertising spaces $(57,1 \%)$ and to optimize entertainment programs (28,6\%) (Figure 4). Foreign TV series, films and documentaries are analyzed on a smaller scale. Neither informative nor educative contents have been tested by private broadcasters.

\section{European private broadcasters finance most studies to increase the efficiency of advertising spaces and to optimize entertainment programs}

Methodological design determines the cost of studies. Consultancies adopt the most varied techniques under the umbrella of neuromarketing (Figure 5). The most used technique is electroencephalography (EEG) (50\%), which monitors electrical brain activity (Vecchiato et al., 2011), and eye-tracking (ET) (42,9\%) that tracks visual patterns to provide information related to individuals' attention. Both are usually employed together since ET allows companies to determine what particular stimulus is producing a certain neural activation.

The use of neuromarketing by broadcasters is increasing positively and it seems this trend is kept in the near future. However, its level of introduction will clearly determine how well or poorly the market research is performed on TV field. Eventually, neuromarketing will rely on cost and benefits to the entertainment industry.

In the mid-term (5 years), the use of neuromarketing research is expected to become more common among media. The professionals trust on the increment of neuroscientific studies in their respective national markets (mean of 7,1) and on the remaining European countries (mean of 6,8 ). In their opinion, neuromarketing is not a temporary trend and the main arguments supporting this assertion are summarized in Figure 6.

$85,7 \%$ of the experts consider that neuromarketing will be widely known among broadcasters in a five year-period and will improve its ability to provide better information, entertainment and educative TV content. The use of these techniques by rivalry companies seems to be an encouraging factor for their application (71,4\%). Also current technology and data interpretation limitations will be overcome in a near future $(57,1 \%)$ and other techniques such as big data will fail to provide cheaper or more useful techniques

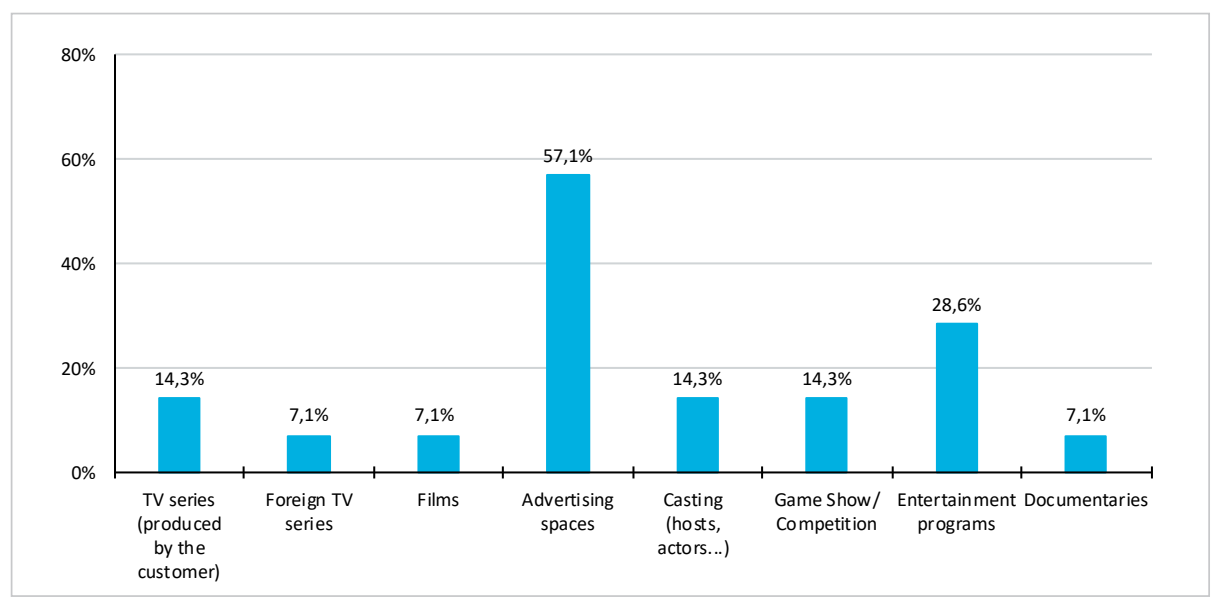

Figure 4. Type of content analyzed through neuromarketing techniques

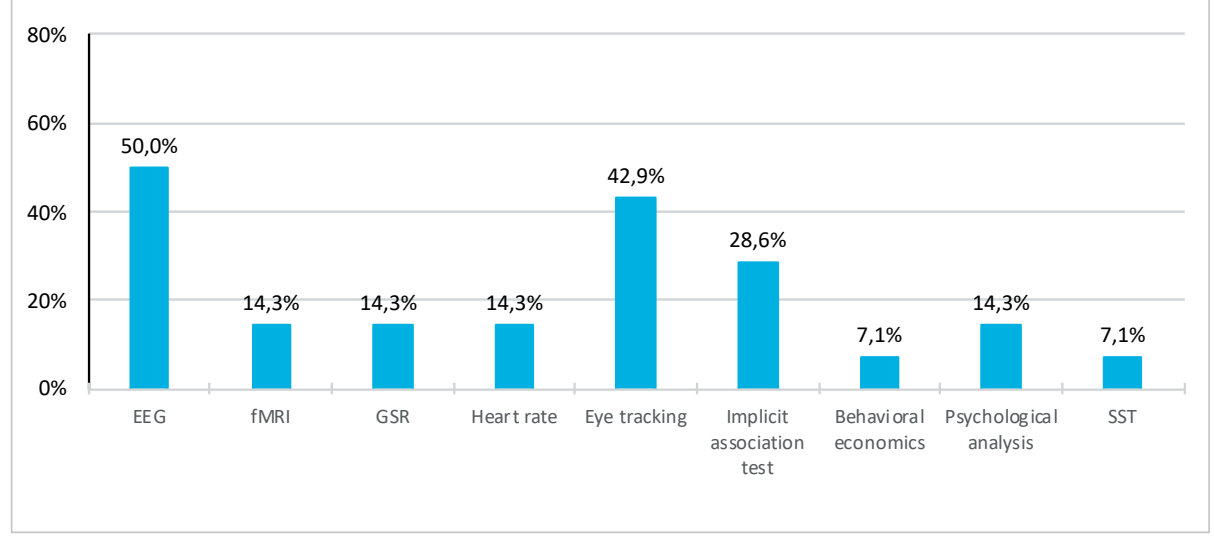

Figure 5. Neuromarketing techniques used to analyze the content

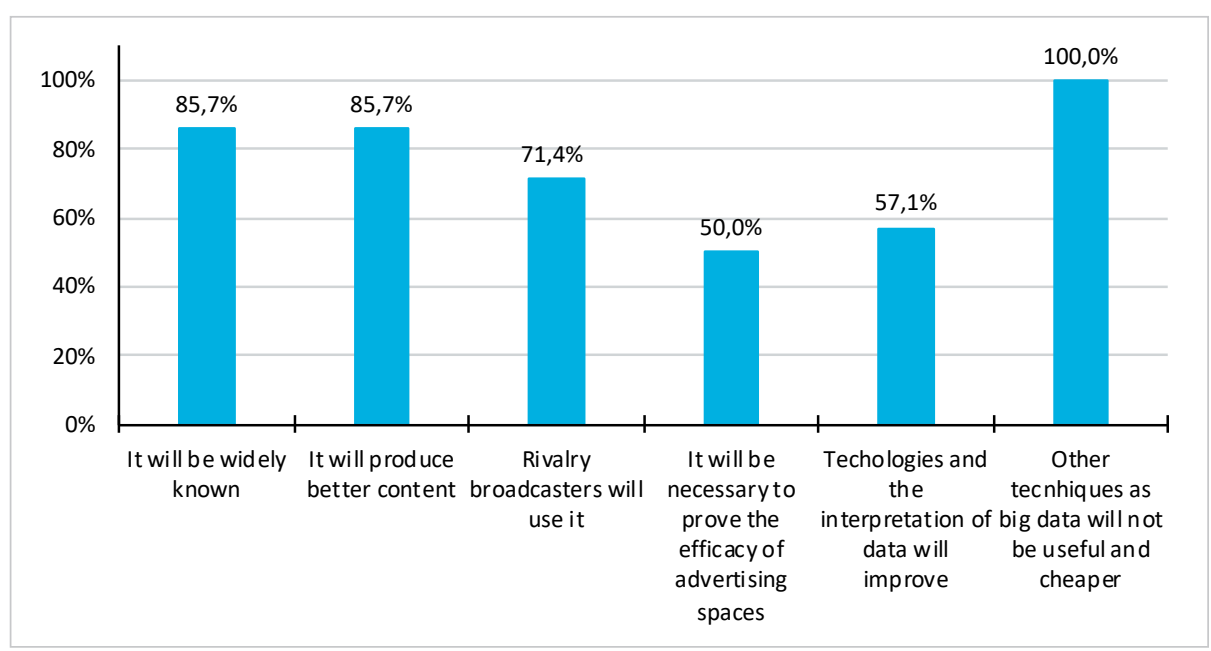

Figure 6. Arguments supporting the future application of neuromarketing techniques 
than neuromarketing in the following years (100\%). This methodology will be needed to prove TV commercial spaces efficacy (50\%).

\section{Conclusions}

The competence of the media scenario leads to a better understanding of the audience. Neuromarketing offers

an alternative formula to explore the audience' attention, memory and emotion to audiovisual stimuli that would lead to optimize the managerial actions of broadcasters and the return on investment for advertisers.

The main focus of neuroscience-based research by private worldwide broadcasters lies on gaining efficacy on linear commercial spaces through the impact of ad formats and on new multi-platform experiences. Neuromarketing itself has become a persuasive argument to sell ad spaces and prove channels' commitment to the advertising industry.

It is important to note that previous research was developed on the implementation of neuromarketing methodology in the private sector, but restricted to Spanish broadcasters. Then, the current study extends its scope to other European countries, although some limitations must be mentioned. Mainly, the reduced sample (14) achieved, due to the small size of the universe of experts in the private industry who agreed to share their strategies. In consequence, only exploratory tools were applied to analyze the participants' responses, collected from more than 30 questions.

One conclusion of the current study is that financed neuromarketing research is developed in Europe, in almost a dozen private channels and at least six public broadcasters. Only a few consultancies have private and public broadcasters as clients and its volume of work remains low when compared to other industries such as advertising. Research is primarily addressed to analyze advertising efficacy, whereas a second objective becomes the optimization of entertainment content, mainly prime time TV series and films. Neither informative nor educative products have been tested by private broadcasters.

Since methodological design determines the cost of studies, EEG and eye-tracking are among the most employed techniques, for their affordable cost of commercial devices and their manageable performance. However, these tools need to overcome some barriers affecting technical issues and data interpretation, which are expected to be surpassed in the near future, due to the technical improvement and the development of a know-how in the entertainment field. Big data is claimed not to affect neuro-based-research since they do not necessarily offer a better value for money.

The future implementation of neuromarketing in the private industry seems to be strongly dependent on its effectiveness to accomplish broadcasters' demands and to increase their business profits. In this respect, exploiting the potential of neuromarketing to reveal hidden information from audience becomes the cornerstone.
Worldwide private channels have promoted neuroscience-based-research to optimizing TV shows and their promotional campaigns, advertising spaces and social TV and multi-screening viewing experience

\section{References}

ARF (2016). Rebirth of a king: The premiere of Spike TV's Tut. Audience measurement 2016. http://goo.gl/GyDqbZ

Aversano, Dan; Marsh, Pamelia; Shalhoub, Huda (2014). "Sync apps: leveraging the power of second screen apps for TV advertising". In: ARF Experiential learning. RE: Think conference, pp. 2-8.

https://www.researchgate.net/publication/269633341_Sync_apps_Leveraging_the_power_of_second_screen_apps_ for_TV_advertising

Babu, S. Samuel; Vidyasagar, Thalluri-Prasanth (2012). “Neuromarketing: is Campbell in soup?”. The IUP journal of marketing management, v. 11, n. 2, pp. 76-100. http://www.iupindia.in/1205/Marketing\%20Management/Neuromarketing.html

Bagozzi, Richard, P.; Gopinath, Mahesh; Nyer, Prashanth U. (1999). "The role of emotion in marketing”. Journal of the Academy of Marketing Science, v. 27, n. 2, pp. 184-206. https://doi.org/10.1177/0092070399272005

Bartelme, Tony (2012). “Meet Carl Marci: A doctor who wants to measure your emotions”. Physician executive, v. 38, n. 1, pp. 10-14.

https://www.ncbi.nlm.nih.gov/pubmed/23885503 
Bechara, Antoine; Damasio, Antonio R. (2004). "The somatic marker hypothesis: A neural theory of economic decision". Games and economic behavior, v. 52, n. 2, pp. 336-372.

https://doi.org/10.1016/j.geb.2004.06.010

Bell, Lynne; Vogt, Julia; Willemse, Cesco; Routledge, Tim; Butler, Laurie T.; Sakaki, Michiko (2018). "Beyond self-report: A review of physiological and neuroscientific methods to investigate consumer behavior". Frontiers in psychology, v. 9, n. 1655. https://doi.org/10.3389/fpsyg.2018.01655

Bénilde, Marie (2016). "Des cerveaux disponibes". Le magazine de I'homme moderne, March, 9. http://www.homme-moderne.org/societe/media/benilde/cerveaux/extraits1.htm/\#note8

Bolls, Paul D.; Lang, Annie; Potter, Robert F. (2001). "The effects of message valence and listener arousal on attention, memory and facial muscular responses to radio advertisements". Communication research, v. 28, n. 5, pp. 627-651. https://doi.org/10.1177/009365001028005003

Brain2Market (2016). Brain2Market. RTI Interactive Gruppo Mediaset. https://www.youtube.com/watch?v=dqtxokjxP68

Cablefax Staff (2011). "Greeks and geeks respond similarly to Spike TV's GCA Awards". Cablefax Staff, September 8. http://www.cablefax.com/programming/greeks-and-geeks-respond-similarly-to-spike-TV-39-s-gca-awards

Cohen, Claude (2005). “Claude Cohen, spécialiste en décervellage publicitaire”. La base Oncle Bernard, January 5. http://labaseob.free.fr/article.php3?id_article=20

Consumer 360 (2012). "CBS neuroscience case study: building a better, faster ad for your brain”. Consumer 360. News \& insights, June 26.

http://www.consumer360.com/cbs-neuroscience-case-study-building-a-better-faster-ad-for-your-brain

Crespo-Pereira, Verónica; Martínez-Fernández, Valentín-Alejandro; Campos-Freire, Francisco (2017). "La neurociencia para la innovación de contenidos en la televisión pública europea”. Comunicar, v. 25, n. 52, pp. 9-18.

https://doi.org/10.3916/C52-2017-01

Crespo-Pereira, Verónica; Martínez-Fernández, Valentín-Alejandro; García-Soidán, Pilar (2016). “El profesional del neuromarketing en el sector audiovisual español”. El profesional de la información, v. 25, n. 2, pp. 209-2916.

https://doi.org/10.3145/epi.2016.mar.07

Crunchbase (n.d.). Customers.

https://www.crunchbase.com/organization/braingineers\#/entity

Ellis, Rob; Greenbank, Martin (2015). "Watching the devices: Do we watch video differently on smaller screens?". Warc. https://www.warc.com/content/paywall/article/esomar/watching_the_devices_do_we_watch_video_differently_on_ smaller_screens/105556

Falk, Emily B.; Berkman, Elliot T.; Mann, Traci; Harrison, Brittany; Lieberman, Matthew D. (2010). “Predicting persuasion-induced behavior change from the brain". The journal of neuroscience, v. 30, n. 25, pp. 8421-8424.

https://doi.org/10.1523/JNEUROSCI.0063-10.2010

Fischer, Carl; Chin, Lisa; Klitzman, Robert (2010). "Defining neuromarketing: Practices and professional challenges". Harvard review of psychiatry, v. 18, n. 4, pp. 230-237.

https://doi.org/10.3109/10673229.2010.496623

Fugate, Douglas L. (2007). “Neuromarketing: A layman's look at neuroscience and its potential application to marketing practice". Journal of consumer marketing, v. 24, n. 7, pp. 385-394.

https://doi.org/10.1108/07363760710834807

Fugate, Douglas L. (2008). "Marketing services more effectively with neuromarketing research: A look into the future". Journal of services marketing, v. 22, n. 2, pp. 170-173.

https://doi.org/10.1108/08876040810862903

Hakim, Adam; Levy, Dino J. (2019). “A gateway to consumers' minds: Achievements, caveats, and prospects of electroencephalography-based prediction in neuromarketing". Wiley interdisciplinary reviews. Cognitive science, v. 10, n. 2 , e1485. https://doi.org/10.1002/wcs.1485

Haq, Amber (2007). "This is your brain on advertising". Bloomberg, Oct 9.

http://www.bloomberg.com/bw/stories/2007-10-08/this-is-your-brain-on-advertisingbusinessweek-business-newsstock-market-and-financial-advice

Harris, Joanne; Ciorciari, Joseph; Gountas, John (2018). “Consumer neuroscience for marketing researchers”. Journal of consumer behavior, v. 17, n. 3.

https://doi.org/10.1002/cb.1710 
Innerscope Research (2014). Welcome to integrated consumer neuroscience. Understanding consumers more completely than ever before. Innerscope Research.

https://www.scribd.com/document/211245362/Integrated-Consumer-Neuroscience-Innerscope-s-2014-Guide

Innerscope Resarch (2015). Innerscope research study shows TV and digital pre-roll significantly stronger platforms for video advertising than Facebook. Innerscope Research.

Lang, Annie; Potter, Deborah; Grabe, Maria-Elizabeth (2003). "Making news memorable: Applying theory to the production of local television news". Journal of broadcasting \& electronic media, v. 47, n. 1, pp. 113-123.

https://goo.gl/2gA4rr

https://doi.org/10.1207/s15506878jobem4701_7

Lang, Annie; Zhou, Shuhua; Schwartz, Nancy; Bolls, Paul; Potter, Robert (2010). "The effects of edits on arousal, attention and memory for television messages: When an edit can be too much?". Journal of broadcasting \& electronic media, v. 44, n. 1, pp. 94-109.

https://goo.gl/RBGkFS https://doi.org/10.1207/s15506878jobem4401_7

Marktforshung (n.d.). Marktforschung mit neuromarketing.

http://www.marktforschung-mit-neuromarketing.de/seite-31.html

Neurosense (n.d.). Clients.

https://www.neurosense.com/2019/09/08/the-science-behind-implicit-reaction-speed-irs-testing

Nielsen (2011). “Nielsen acquieres Neurofocus". Nielsen, May 26.

http://www.nielsen.com/us/en/press-room/2011/nielsen-acquires-neurofocus.html

Nielsen (2015). “Nielsen creates the world's largest consumer neuroscience organization with acquisition of Innerscope Research". Nielsen, May 29.

http://sites.nielsen.com/newscenter/nielsen-creates-the-worlds-largest-consumer-neuroscience-organization-withacquisition-of-innerscope-research

Nielsen (2016). How market research contributed to understanding the impact of shared news content on consumers. http://researchchoices.org/content/public/w5G/leveraging-the-power-of-social-media

Oakes, Omar (2016). "Channel 4 launches TV and advertising research PhD with Durham University”. Campaign, July 19. http://www.mediapost.com/publications/article/280579/channel-4-launches-a-phd-in-TV-advertising-neurosc.htm/

Penenberg, Adam L. (2011). "Neurofocus uses neurmarketing to hack your brain". Fast company, August 8. https://www.fastcompany.com/1769238/neurofocus-uses-neuromarketing-hack-your-brain

Pop, Nicolae Al; Dabija, Dan-Cristian; Iorga, Ana-Maria (2014). "Ethical responsibility of neuromarketing companies in harnessing the market research. A global exploratory ap- proach". Amfiteatru economic, v. 16, n. 35, pp. 26-40. http://www.amfiteatrueconomic.ro/temp/Article_1249.pdf

Pratesi, Carlo-Alberto; Mattiacci, Alberto (2015). "Social media marketing". Spaghetti marketing, December. http://goo.gl/ckAuFB

Pynta, Peter; Seixas, Shaun A. S.; Nield, Geoffrey E.; Hier, James; Millward, Emilia; Silberstein, Richard B. (2014). "The power of social television: Can social media build viewer engagement?". Advertising research, v. 54, n. 1, pp. 1-15. https://doi.org/10.2501/JAR-54-1-071-080

Santos, Rene; Oliveira, Jorge; Rocha, Jessica; Giraldi, Janaina (2015). “Eye tracking in neuromarketing: A research agenda for marketing studies". International journal of psychological studies, v. 7, n. 1, pp. 32-42.

https://doi.org/10.5539/ijps.v7n1p32

Seixas, Shaun A.; Nield, Geoffrey E.; Pynta, Peter; Silberstein, Richard B. (2015). "The neuroscience of social television". En: Hajli, Nick. Handbook of research on integrating social media into strategic marketing. Newcastle: IGI Global, pp. 153-166. ISBN: 9781466683532

https://doi.org/10.4018/978-1-4666-8353-2.ch010

Sensum (2016). "Football legend lan Wright works with Sensum to rate the success of 4K TVS". Sensum, February 9. https://sensum.co/blog/football-legend-ian-wright-works-with-sensum-to-rate-the-success-of-4k-tvs

Siefert, Caleb; Gallent, Janet; Jacobs, Devra; Levine, Brian; Stipp, Horst; Marci, Carl (2008). “Biometric and eye-tracking insights into the efficiency of information processing of television advertising during fast-forward viewing". International journal of advertising, v. 27, n. 3, pp. 425-446.

https://doi.org/10.2501/S0265048708080050

Singer, Natasha (2010). "Making ads that whisper to the brain". The New York Times, November 13.

http://www.nytimes.com/2010/11/14/business/14stream.html 
Snptv (2003). Etude Snptv/Impact mémoire: Mémoire et publicité TV.

https://www.snpTV.org/newsletters/etude-snpTV-impact-memoire-memoire-et-publicite-TV

Snptv (2005). Communiqué Snptv/IM!: Mémoire et publicité TV.

https://www.snpTV.org/newsletters/communique-snpTV-im-memoire-et-publicite-TV

Steele, Audrey; Jacobs, Devra; Siefert, Caleb; Rule, Randall; Levine, Brian; Marci, Carl D. (2013). "Leveraging synergy and emotion in a multi-platform world". Journal of advertising research, pp. 417-430.

https://doi.org/10.2501/JAR-53-4-417-430

Swant, Marty (2016). "Time Warner and Nielsen will study how virtual reality affects the subconscious". Adweek, April 5. http://www.adweek.com/digital/time-warner-and-nielsen-will-study-how-virtual-reality-affects-subconscious-170614

Synetiq (n.d.). Synetiq.

https://synetiq.net

TF1 Publicité (2015). “Campus TF1 Efficacité 2011". TF1 Publicité.

http://www.tf1pub.fr/showroom/campus/campus-tf1-efficacite-2011

Thinkbox (2015). "Product placement research". Thinkbox, November 14.

https://www.thinkbox.TV/How-to-use-TV/Sponsorship-and-content/Product-placement/Product-Placement-research

Treleaven-Hassard, Shiree; Gold, Joshua; Bellman, Steven; Schweda, Anika; Ciorciari, Joseph; Critchley, Christine; Varan, Duane (2010). "Using the P3a to gauge automatic attention to interactive television advertising". Journal of economic psychology, v. 31, n. 5, pp. 777-784.

https://doi.org/10.1016/j.joep.2010.03.007

Treutler, Theresa; Levine, Brian (2010). Multi-platform messaging. The medium matters. Television Bureau of Canada, Innerscope Research.

https://www.warc.com/content/paywall/article/MultiPlatform_Messaging_The_Medium_Matters/92350

Treutler, Theresa; Levine, Brian; Marci, Carl D. (2010). "Bio-metrics and multi-platform messaging: The medium matters". Journal of advertising research, v. 50, n. 3, pp. 243-249.

https://doi.org/10.2501/S0021849910091415

Vecchiato, Giovanni; Astolfi, Laura; De-Vico-Fallani; Toppi, Jlenia; Aloise, Fabio; Bez, Francesco; Wei, Daming; Kong, Wanzeng; Dai, Jounging; Cincotti, Febo; Mattia, Donatella; Babiloni, Fabio (2011). "On the use of EEF or MEG brain imaging tools in neuromarketing research". Computational intelligente and neuroscience, v. 2011, art. 643489.

https://doi.org/10.1155/2011/643489

Warc (2015). Warc trends toolkit 2015. Six major marketing trends for the year ahead.

https://www.warc.com/Content/80b65087-b2bf-40e8-abe6-78c26ed77e49

Warc (2016). "Turner scores with neuroscience". Warc, April 4.

https://goo.gl/eeeENq

Warc (2017). "Viacom taps power of neuroscience". Warc, February 21.

https://www.warc.com/NewsAndOpinion/news/Viacom_taps_power_of_neuroscience/79442a74-d589-4b20-8d87$964 d c 99 d 8 a b b$

Woltman-Elpers, Josephine L. C. M. (2003). Consumers' moment-to-moment processing of television commercials. Groningen: University of Groningen. ISBN: 9053350209

http://www.rug.nl/research/portal/files/3002327/thesis.pdf

Zurawicki, Leon (2010). Neuromarketing. Exploring the brain of the consumer. Boston: Springer. ISBN: 9783540778288

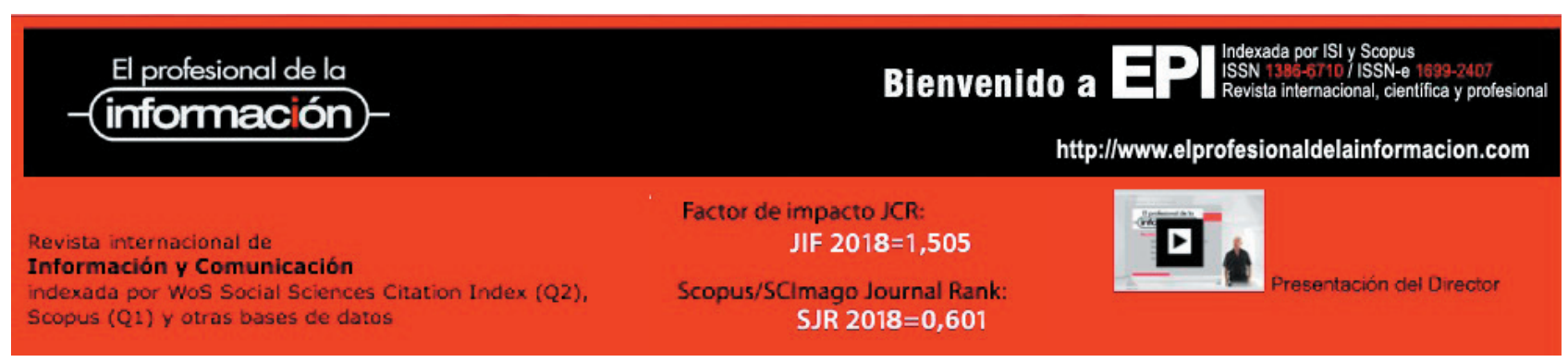

